\title{
Human nose on a plate
}

Joel Mainland

From 1st International Workshop on Odor Spaces

Hannover, Germany. 4-7 September 2013

The characterization of odorant receptor responses to ligands in the empty neuron system of Drosophila melanogaster has allowed researchers to choose rationally diverse odorant sets and specifically manipulate subpopulations of ORs to dissect olfactory coding. In contrast, matching mammalian odorant receptors to ligands has seen limited success, and the picture is even worse when considering human odorant receptors; ligands have been published for only 21 of the approximately 400 intact human odorant receptors. This lack of data is a critical bottleneck in the field; matching ligands to odorant receptors is critical for understanding the olfactory system at all levels and is essential for building viable models of olfaction. Matching odorants to human odorant receptors has the advantage that humans can directly communicate their perception of odor intensity, pleasantness, and quality. We have developed a high-throughput screening system capable of screening the entire human olfactory receptor repertoire. In this talk we will explore the technique of cell-based olfactory receptor screening techniques and its applications in probing odor coding.

Published: 16 April 2014

doi:10.1186/2044-7248-3-S1-07

Cite this article as: Mainland: Human nose on a plate. Flavour 2014

3(Suppl 1):O7.

Monell Chemical Senses Center, Philadelphia PA, USA

Submit your next manuscript to BioMed Central and take full advantage of:

- Convenient online submission

- Thorough peer review

- No space constraints or color figure charges

- Immediate publication on acceptance

- Inclusion in PubMed, CAS, Scopus and Google Scholar

- Research which is freely available for redistribution 